\title{
UMĚNÍ KRAJINY - KRAJINNÝ DESIGN JAKO ESTETICKÝ PROCES
}

\author{
JAN HENDRYCH
}

\section{Úvod}

Tradiční krajina jako dialog člověka s př́rodou je svébytný a dlouhodobý dynamický proces zrcadlící nejen základní lidské potřeby, ale i člověku přirozenou snahu o dokonalé a esteticky libé uspořádání prostředí. Způsoby hospodaření a osidlování krajiny si během tisíciletí osvojily principy, postupy a technologie, které předvídaly a akomodovaly limity př́rody. Člověk byl součástí místa, z něj bral a jemu vracel. Lidské dílo vycházelo z měřítka člověka a stejně jako on př́rodu, př́roda si přizpůsobovala jeho činnost; procesy sukcese dotvářely a narušovaly lidské uspořádání, stejně jako hospodářská a prostorotvorná činnost narušovala př́rodní řád. Tento dynamický vztah vzájemného narušování a dotváření, umocněný neustálými proměnami, růstem a zráním, se mohl stát nejen velmi pestrým v jednotlivostech, ale i dlouhodobě harmonickým, pokud došlo k jeho ideálnímu ustálení a trvale vyváženému hospodářskému udržování lidských měřítek a poměrů. $\mathrm{V}$ takovém prostředí mohl být člověk štasten, nebot odpovídalo jeho ustrojení a obráželo jeho chápání $a$ vidění světa a potvrzovalo v něm jeho místo. At̉ instinktivně, nebo záměrně, na malém, či velkém prostoru, člověk vždy své prostředí uspořádával a estetizoval ke svému obrazu, potvrzoval tím svou existenci a místo ve světě; často uprostřed př́rody, která byla jeho nedílnou součástí a do značné míry ovlivňovala jeho činnost. Krajinný design byl odpradávna nástrojem $\mathrm{s}$ jehož pomocí byly $\mathrm{v}$ krajině akomodovány a uspořádávány lidské potřeby. ${ }^{1}$

\section{Základní pojmy}

Etymologicky se pojem landscape (krajina) vyvíjel z prapůvodních landskift, landscipe a landscaef, užívaných v Británii od pátého století n. l., a vztahujících se k systémům člověkem utvářených prostor na zemi. $V$ němčině landschaft označoval malé administrativní území či region. Podobně v italštině paessagio odkazuje k paese, značící teritorium, region, zemi, ale také půdu, ve smyslu srovnat, zarovnat, uhladit. Jedná se o fenomén

\footnotetext{
Záměrně v tomto př́spěvku odlišuji pojem krajinného designu, jako dávné civilizační potřeby člověka a nástroje, od dnes obecně užívaného pojmu krajinná architektura, který vznikl po polovině 19. století v USA v souvislosti s érou zakládání městských parků, řešení urbanistických a sociálních problémů rostoucích aglomerací; v podstatě nebyla tehdejší krajinná architektura konfrontována s historicky významněji a dlouhodoběji utvářeným prostředím krajiny (všude byla jen př́roda a indiáni v rezervacích). Počeštěný a dnes užívaný termín krajinářská architektura pak prozrazuje těsnou př́slušnost k oborům zahradnickým, tvorbě krajinářských parků, sadovnictví a jejich přerůstání do krajiny.
} 
spjatý s člověkem, jeho činnostmi, prací. V češtině krajina obecně odkazuje na okraj, kraj svého stř̌edu, těžiště, uzlového bodu; vizuálně rozeznatelný prostor, zpravidla sídla s morfologicky definovatelným okolím. Krajina je tak prostorově uceleným jevištěm, kde složky kulturní jsou vizuálně ohraničeny (okrojeny) a protkány složkami př́rodními (horizonty, lesy). „Krajina je tedy lidský fenomén, mající charakter horizontu bližšího než svět a př́íbuzný obzoru domova" [Gojda 2000: 59].

Pestrou mozaiku kultur a tradic kontrastně rámovala stejně pestrá mozaika hospodářsky utvářených krajin, od sídel až po okolní přírodu. Tato mozaika byla protkána sítí dálkových komunikací (již pohodlné římské silnice např́íč impériem), cest a pěšin, podle významu a určení, mezí (zavedených římským katastrem v základních, cestami členěných celcích cca. $355 \times 355 \mathrm{~m}$, později $710 \times 710 \mathrm{~m}$, uvnitř dělených jednotlivými hony s mezemi), které podobně jako umístění sídel vycházely z morfologie krajiny, reliéfu a přirozených trajektorií, překážek terénu a vodních prvků. Dlouhodobě ustálenou mírou člověka a základní prostorovou jednotkou jeho činnosti v krajině se v našich podmínkách stalo katastrální jitro, hon (cca 0,5756 ha), ${ }^{2}$ odvozené z plochy zorané oráčem s potahem od rána do soumraku. Ohraničení takových prostorů zprostředkovalo zpravidla rámování přírodními prvky (stromy, keři, vodotečemi atp.), později cíleným uspořádáním a zvýrazněním těchto a dalších umělých prvků (rozcestníky, stély, sochy, drobná architektura atp.) na funkčně důležitých uzlových a symbolicky významných místech (uzlové body, ohniska, linie).

Schopnost identifikace a strukturování prostředí je existenčním vybavením každého zvířete (smysl pro barvu, tvar, pohyb, světelnou intenzitu, chut', zvuk, vůni a hmatové vjemy, cit pro těžiště věcí atd.) i člověka. [Lynch 1960: 3]

Utváření prostředí krajiny (design krajiny, at záměrný či instinktivní) je nepřetržitým a pokračujícím procesem, kde příroda je polidštěna $v$ krajině a ta se stává uměním. Všechen záměr, úmysl a design obráží minulost i v současné krajině, zahradách, parcích a objektech, byt vzniklých v jiných společenských a sociálních podmínkách [Jellicoe, Jellicoe 1975]. Podle Platona (428-347 př. n. 1.) hmotné objekty (kameny, stromy i člověk) mohou, to je společné všem věcem na světě, dosáhnout a zrcadlit v sobě ideální formu, dokonalost svých nehmotných vzorů. Podle Schopenhauera [1969] člověk je okem přírody, kterým se př́roda sama na sebe dívá; člověk tak disponuje kapacitou pro estetický vjem, prožitek zrcadlení ideálních forem, dokonalosti. Objekty (ale i prostory), které komunikují tyto zkušenosti, jsou pak nositeli estetických hodnot (viz také prŕrodní vzor, archetyp). ${ }^{3}$ Estetický vjem je vlastností intelektu, výsledkem rozumového procesu a rozeznání ideálních vlastností a forem; nejen záměrně vytvořených, ale i v přírodě jsoucích a vjemově rozpoznaných, instinktivně či nakonec záměrně kultivovaných a designovaných. „Nic se neozřejmuje jen samo o sobě, ale vždy jen ve vztahu k okolí a v návaznosti na

2 Malý slovník jednotek měření, vydalo nakladatelství Mladá fronta 1982, katalogové ćíslo 23-065-82. Jedno jitro staročeské (jitro pražské) $=2837$ metrů čtverečních $=1 / 72$ lánu podle Hájkovy kroniky: jedno jitro $=1$ hon $=3085$ metru čtverečního, jednalo se o obdélník o stranách 42 krát 210 loktů. Po zavedení systému dolnorakouských měr v roce 1764 užíváno vídeňské jitro neboli katastrální jitro (Joch) $=5756$ metru čtverečního.

3 Ideální, abstraktní formy objektů (samotná esence a podstata, paradigma, koncept a vzor; u Platóna božský model kosmu), ležící mimo prostor a čas; jsou trvalé a uchopitelné vjemově a rozumově. 
sled událostí, neustálý vývoj, které prostř̌edí vytvářely.“ [Lynch 1960: 1-2] Odraz poznání, která přinášely přírodní vědy, vrcholící Darwinem a jeho evoluční teorií, později silně ovlivnil chápání estetiky prrírody; již naplno se hovoří o kráse př́rody [Stibral, Dadejík, Zuska 2009]. Pro Josefa Durdíka je tak již příroda př́mo estetickým objektem, objektem prrírodních věd. Estetické vnímání přírody shrnul ve svém díle Všeobecná aesthetika, kde v podstatě uvažuje estetiku př́rody jako samostatný studijní obor [Durdík 1875 in Stibral, Dadejík, Zuska 2009: 57]. Typičnost podle Durdíka náleží ke kráse, je to dokonalost a schopnost obrazu svého vzoru, ideální formy [Stibral, Dadejík, Zuska 2009: 60].

Poměry lidského díla $\mathrm{v}$ krajině a jeho obrazu $\mathrm{v}$ př́rodě vycházejí $\mathrm{z}$ utváření člověka a jeho vztahu k prostředí. Podle Prótagoráse, člověk je mírou všech věcí (věci mají ty vlastnosti, které jim dává člověk). ${ }^{4}$ Plutarchos (46-127 n. l.) zmiňuje stromy na Aténské agoře, od Strabóna (64 př̀ n. 1. - 24 n. l.) známe popis stinné aleje a sloupořadí (sloupy stoiků) Alexandrijského Museionu. Po řeckém vzoru člověk žije ve shodě s věcmi, kterými jej obdařila př́roda; Vitruvius doporučuje a zdůrazňuje vysazování stromořadí (pravidelně uspořádaných př́rodních prvků) podél kolonád, lázní, chrámů, veřejných prostranství. Marcus Vitruvius Pollio (70-80 př. n. 1. - 15 pr. n. 1.) ve spisu De architectura rozebírá vhodné postupy zakládání hospodářských usedlostí v krajině, reflektuje klasické řecké př́klady. Toto dílo, jediné dochované svého druhu, zásadně ovlivňovalo i učence, umělce a architekty renesance.

\section{Renesance krajiny}

Italská renesance, inspirovaná antikou, hledala dokonalé formy objektů v jejich př́irodní podstatě, ve vztahu lidského měrítka $\mathrm{v}$ ideálním řádu prostoru a světa. Leonardo da Vinci (1452-1519) v úvahách o architektuře zdůrazňuje význam lidského měřítka pro uspořádání prostoru, př́roda je u něj zásadním zdrojem inspirace, objektem studia a napodobování. Doporučuje stavět ulice tak široké, aby odpovídaly průměrné výšce okolních domů, před paláci zřizovat veřejné prostory, náměstíčka. Varuje před nepohledností velkých ploch kostelních střech, které oko nepotěší. Všímá si, skicuje a popisuje vizuální působivost a bohatství horské přírody Alp, společně s líčením lidských aktivit. Je to pohled renesančního cestovatele, který líčení scény dokládá vlastní zkušeností zdolávání hor a užívání si místní pohostinnosti za dobrou láci:

Nad jezerem Como leží údolí Chiavenna, z něhož do jezera vtéká řeka Mera. Po řece se sváží velké náklady dříví. Nacházejí se zde velmi vysoké, neúrodné hory s obrovskými skalami. Je nemožné se na ně vydrápat bez použití všech končetin. Nad nimi létají vodní ptáci zvaní racci. Rostou zde jedle, modříny a borovice. Žijí zde jeleni, divoké kozy, kamzíci a medvědi hnědí. Rolníci tam chodí v dobách sněhu s velkými oky a chtějí medvědy donutit slézt z těchto skal. Nad řekou se nacházejí vodopády o 400 pažích na výšku, které jsou na pohled velmi působivé. Občas narazíte na dobrý hostinec. Dobře se tu pomějete za 4 groše. [Da Vinci 2010: 104]

4 (481 př. n. l. Abdéra v Thrákii - 410 př̀. n. 1.). „Mírou všech věcí je člověk - jsoucích, že jsou, a nejsoucích, že nejsou." 
Kresebné studie věnuje detailům skal a podhorských krajin s vodopády i sídly, krajině Toskánska z ptačí perspektivy; věrná jsou horská pozadí obrazů z přelomu 15. a 16 . století. Krajina řeky Arno, Ponte Buriano, tvoří pozadí Giocondy. Na jiném místě deníku líči půvaby a krásu kopcovité kvetoucí krajiny Kypru:

Na jih od pobřeží Sicílie je možno spatřit půvabný ostrov Kypr, říši bohyně Venuše. ... Krása zdejších kopců láká putující námořníky, aby si odpočinuli mezi květinami a zelení, tam, kde vane jemný vánek naplňující ostrov a okolní moře nádhernými vůněmi. [Da Vinci 2010: 113]

Píše o duchu přírody a růstu, realizaci daru Boha na zemi prostřednictvím zemského ducha růstu, lidské práce, tvorby, intelektu a potřeby, kterou rozpoznal jako sílu podřízenou zákonům prírody.

Můžeme tedy říci, že země má ducha růstu. Tam, kde není vnímající, rostlinný nebo inteligentní život, nic nevznikne. Bože, prodáváš nám všechny dobré věci a my Ti platíme prací. Badatelé, nevychloubejte se, že znáte to, co se běžně nachází v přírodě, ale radujte se, víte-li o věcech, které sami vymyslíte. Potřeba je milenkou a průvodkyní př́rody, je hlavní myšlenkou, vynálezcem, věčným omezením a zákonem př́rody. [Da Vinci 2010: 126]

Jeho myšlenky, stavící na jednotě věcí a jejich vzájemných vztahů, vycházejí z matematické podstaty světa pythagorejců, z Platónových dokonalých idejí, jichž věci jsou jen odrazem a stínem, toužícím po přiblížení se dokonalosti svých nehmotných vzorů. Obrážejí učení Stoiků a úvahy novoplatoniků florentské Akademie, předbíhají myšlenky Shaftesburyho (představa bohem uspořádané a harmonické prrírody, vesmíru, kde estetický vjem a soud je přesným obrazem tohoto harmonického kosmického řádu, božího díla), Rousseaua a Kanta. Otázky př́rodní estetiky nedávno uceleně shrnul Stibral a kol. [Stibral, Dadejík, Zuska 2009]

V antikou inspirovaném renesančním Toskánsku systém hospodářské krajiny, často uprostřed horských lesů, byl součástí obnoveného klasického konceptu vily v krajině, známého z popisů Plinia ml. (61-112), nověji i Leona Battisty Albertiho (1404-1472). Systém, jehož prostorové členění bylo dáno hospodářským životem, byl znovunalezeným základem kultivace krajiny. Stavějíc právě na klasických odkazech a filosofii, byla od renesance krajina již zcela záměrně uspořádávána prostřednictvím krajinného designu jako prostorový útvar (symbol, znak, umělecké dílo), kde efekt byl dosahován jednoduchostí formy; stojíc na uměle vytvořené a přirozeně působící dominantě stromových cest (lecce), nejprve v prostorech zahrad, loveckých lesních obor (barco), vinic (vigna) a postupně přecházejících do širšího okolí krajiny, mnohde kultivované v prastarém rámci a členění původního římského katastru. ${ }^{5}$

5 Známým př́kladem je historická, avšak dnes již značně industrializovaná, hospodářská krajina při zaniklých meandrech řeky Santerno, doposud členěná římským katastrem mezi městy Imola, Massa Lombarda a Lugo; $44^{\circ} 23^{\prime} \mathrm{S}, 11^{\circ} 44^{\prime} \mathrm{V} / 44^{\circ} 19^{\prime} \mathrm{S}, 11^{\circ} 55^{\prime} \mathrm{V} / 44^{\circ} 26^{\prime} \mathrm{S}, 11^{\circ} 50^{\prime} \mathrm{V}$. U Latiny při Via Appia pak např. na $41^{\circ} 22^{\prime} 44^{\prime \prime} \mathrm{S}, 13^{\circ} 07^{\prime} 11^{\prime \prime} \mathrm{V}$. 
Sepětí estetična s krajinou a prŕírodou shrnul Šindelář:

Estetická funkce původně fixovala to, čím se člověk začal lišit jako rodová bytost od ostatních forem života, totiž vědomou péčí o dokonalost. $Z$ dávných dob se $\mathrm{v}$ nás uchovala bázeň $\mathrm{z}$ prázdného prostoru, nebo alespoň nechut jako $\mathrm{k}$ něčemu, co postrádá lidský význam. Proto prostor zaplňujeme věcmi. Tato potřeba se projevuje i v potřebě pojednávat s prostorem v procesu našeho vidění a ovládání světa. Jsou potřeby, které jsou neodlučitelně spjaty s našimi instinkty a fyziologií, s pracovními úkony atp. Všechny mohou nalézt své potvrzení vnějším znakovým objektem, který je vzhledem k potřebě vhodný, tedy funkční, nebo je pro tento cíl zvlášt zhotoven. Estetická funkce je znamením zobecnění a tím i uspokojení té které potřeby prostřednictvím významového tvaru. Snaha estetizovat si skutečnost jde až tak daleko, že se i příroda začíná stylizovat. [Šindelář 1969: 237] Uspořádané prostředí se uplatňuje jako symbol, nebot’ v něm se teprve člověk cítí potvrzen jako lidská bytost. Tady se završuje Sokratova myšlenka o kráse jako účelovém uspořádání. [Šindelář 1965: 220]

Krajina se stala nositelem nových společenských hodnot, nejen starých mýtů (strach $\mathrm{z}$ divoké prrírody, z lesa, hor, které ovšem v obecném povědomí dlouho přetrvávaly). Estetika umění přesáhla do krajiny sadů, vinic a polí, které byly chápány jako člověkem strukturovaná prŕíroda, smysluplné uspořádání života a světa. Tento aspekt byl zvýrazněn i pravidelností výsadeb, od květin až po ořechové a kaštanové háje a lesy; řadami stromů i alejemi, které zprostředkovaly funkční propojení vil a sídel se zahradami, vinicemi, oborami a drobnými hospodářstvími v krajině. Speciálním znakem kultivace krajiny se staly aleje a stromořadí, kde užitkové aleje a stromořadí byly vysazovány s ohledem na estetický účin a kompozici. Řady stromů v liniích a ve stejných odstupech (dle tradice určených již Šalomounem), v symbolické pětici quincunx, ${ }^{6}$ se sázejí do uspořádaných řad, vytvářejí postupně klenbu (loubí, lecce), jsou univerzálním symbolem spojení lidského a přírodního řádu. Tak se pozdně středověká ragnaia, určená k čižbě, profilovala do vysokých stěn zeleně i dominantních cypřišových alejí Toskánska. ${ }^{7}$

Rostoucí estetický zájem o krajinu a přírodu je od renesance, mimo malířství a literaturu dokumentován proměnami umění zahrad a krajinného designu, kde společné prostorotvorné prvky a postupy zahradnického umění a architektury začínají formovat vzorová zemědělství (Sancta Agricoltura) na severu Itálie, v duchu benátské renesance a za podpory průkopníka hydrauliky a meliorací, patrona umění Alvise Cornara (1484-1566) i malíre architekta Giovanni Maria Falconeta (1468-1535, který architekturu renesance přenesl z Ríma a Florencie na sever Itálie) a vrcholící díly Andrea Palladia [Benzoni 2004]. Villa Badoer (La Badoera, 1556-1563) byla v konceptu inspirována nejen Palladiovými výzkumy ř́mských vil v Tivoli, ale i Medicejským Poggio a Caiano

6 Cicerovo De Senectute, příběh Cyra, krále Persie, jenž ve své zahradě vysazoval stromy v rastru pětice quincunx. Příběh byl oblíbený v renesanční Itálii, stejně jako později po celé Evropě; viz Thomas Brown (1658) The Garden of Cyrus. Quincunx, symbol pětice, Brown vyložil jako mystické propojení umění, přírody a vesmíru; symbol božského díla na zemi prostřednictvím lidské ruky a prírody.

7 Čižba, kde vysoké stř́ihané stěny stálezelené vegetace, $\mathrm{k}$ hnízdění ptactva, jsou uspořádány jako pavučina či v řadách vedle sebe. 
(po 1485) od architekta Giuliana da Sangalla (1443-1516), při níž Lorenzo Medicejský (1449-1492) zrrídil okrasné vzorové hospodářství La Cascine di Poggio a Caiano. Zde, na ploše 10000 hektarů, byla utvářena ideální krajina vévodství. Rovinaté pozemky u řeky Ombrone svědčily obilovinám, rýži, zelenině, svažitější terén na jihu pak zabíraly vinice a sady, louky, čižby (ragnaia) v podobě stromořadí vrcholících roccoly (čihadla, drobné věžové stavby s otvory ke sledování a lovu ptactva), boscy, bažantnicemi v oboře Barco Reale Mediceo, jejíž zed' čítala délky 50 kilometrů. ${ }^{8}$ Palladiovy vily Emo, Almerico Capra či Barbaro (mimo jiné) pak nejlépe ilustrují estetický účin kompozic alejí v intenzivní hospodářské krajině.

\section{Diskuse}

Příroda a její prvky byly vneseny do světa člověka, staly se vnímanými vzory obdivu a napodobování, byt' byl tento zájem probouzen pozvolna, podle intelektu, citu, dobových možností. Jak dokládá zájem a zaměření přírodních věd od samotných jejich počátků, vjem estetických hodnot prŕrodních prvků v krajině je obrazem kapacity tyto prvky chápat jako součást představy ideálních forem věcí, jejich seskupení a systémů. Kapacita pro vnímání estetických hodnot přírody, rozvíjená od renesance, přes romantismus až k environmentálnímu pohledu, je výsledkem rozumového procesu, schopného pojmout a formulovat představu pestré, kontrastní a různorodé jednoty věcí ve světě, jehož jsme součástí; schopnosti sebereflexe a respektování podřízenosti jednotě přírody, v níž spočívá i trvalost a udržitelnost. Ideální představa př́írody ovšem bude obsahovat jiné formy, poměry, měřítka (drama, vznešenost), než ideální představa tradiční sídelní krajiny (útulnost, řád, drobné měřítko).

Stejně jako u Leonarda, i u Albrechta Dürera (1471-1528) obdivujeme precizně a do detailu zpracované krajinářské a přírodní motivy, zachycené na cestách po Evropě, později inspirované Alpami a Itálií. Vedle obhospodařovaných Alpských údolí, jako pozadí dějů v krajině (Růžencová slavnost), setkáváme se s přesnými studiemi krajinných a přírodních scén a detailů (Jezero v lese, Velký drn atp.) jako samostatných motivů, ještě $\mathrm{z}$ doby před první italskou cestou.

Básník a humanista Jacopo Sannazaro (1458-1530) v úvodu své Arcadie vyzdvihuje utěšený pohled na př́rodní prostředí rozeklaných hor a vysokých rozložitých stromů a srovnává je s nedokonalými zahradnicky upravovanými napodobeninami. Opěvuje fontány v přírodní podobě vývěrů z živoucích skal, chválí pastorální poesii přírodního parku bez okrasy a rustikálnost lesních pramenů, kde voda prýští přímo z žil prrírody [Sannazaro 1966]. Aeneas Sylvio Piccolomini, v letech 1458-1464 jako papež Pius II., $\mathrm{v}$ pamětech střídá popisy povinností s líčeními př́rodních míst, která navštívil během cest, úniků z nebezpečného Ríma. V nosítkách se nechával vynášet nad vodopády, nosit horskými údolími, kochal se divokou horskou krajinou [Piccolomini 1959].

Malebnost tradiční krajiny, věrného zobrazování stromů, skal, vodních ploch, byla tématem Pietra Brueghela staršího (1525-1569), jehož tvorba nadlouho ovlivnila kraji-

8 Provoz hospodářství pokračoval ještě v době Cosima III. a po úpadku byl částečně obnoven za Pietra Leopolda po r. 1765. V současnosti přírodní park La Cascine di Tavola. 
nomalbu. Upřímnému zájmu se zpodobňování přírody a kontrastních malebných detailů těšilo u císaře Rudolfa II. (1552-1612), sběratele umění, včetně imitací Brueghela, pro něhož je zpracovával povolaný vlámský rytec a krajinář Roelandt Savery (1576-1639). V Nizozemí byl na přelomu 16. a 17. století znám výraz pro malebno (schilderachtig), pro motivy „podle života“, nezkrášlené, přitažlivé, živé, s bohatstvím detailů. Byly to rostliny, stromy, staré chalupy, přírodní útvary, hrady, kostely, rozvaliny, ruiny; u Saveryho také malebná zákoutí měst a ruiny románských rotund v Praze. Saveryho Orfeus, který líbeznou hrou na lyru přivolá $\mathrm{k}$ sobě všechnu živou přírodu, byl mementem vztahu člověka a př́rody [Kotková 2010].

Na pokyn císaře se Savery zabýval systematickým skicováním a malováním přírodních scén Tyrol a Čech. ${ }^{9}$ Vedle rozeklaných skal a alpských údolí s venkovany, rybáři, lovci raků, zobrazoval s oblibou detaily pokroucených kořenů a kmenů prastarých stromů, říčních zákoutí, skalisek a balvanů s bujnou vegetací, lesních scén s peřejemi a vodopády, pastorální a lovecké krajiny i naturalistické scenérie lesních roklí (Lesní bystřina, 1606-1608), inspirované lesními stržemi Alp i Křivoklátských hvozdů.

V šerosvitu Lesní rokle (1608-1610) ožívá podvečerní nálada Vergiliovy poezie (Panofsky [1955] pokládá Vergilia za objevitele krásy podvečerní krajiny); světla a nálady před západem slunce nad Arkádií, která se stává přítomností v lesní krajině na Křivoklátsku. Simon Schama [1996: 100] připomíná Saveryho v souvislosti s Arkádiemi Hercynského lesa; obraz rolníka v lese s ruinami (1616) je proměnou lesního božstva na lidské stvoření, s přírodou smířeného uživatele lesa. Lesní a pastorální krajina tady není jen kulisou klasické architektuře; je vyzdvižena vizuální a malebná kvalita přírodních útvarů a porostů. Divoká př́roda není již jen sídlem antických božstev, ale krajinou lidských bytostí. Nejen Orfea; vedle lovců jsou zde poustevníci, poutníci, hospodáři, rybáři i kreslíri skicující krajinné scenérie. Silueta Hradčan a ruiny pražských rotund jsou Saverym často kontrastně zasazeny do prostředí horských údolí, lesů a přírody. Estetika lesa, prrírodní krajiny skal, roklí, peřejí, vodopádů i stromů, jak byla vnímána velkými umělci renesance a manýrismu, byla znovu restaurována romantiky, řád př́rody se stal trvalou součástí lidského světa, krajiny.

V Anglii tvořící Václav Hollar (1607-1677) si na vedutách měst všímal krajiny, ruin, přírodních detailů. Sestavoval grafické soubory navazujících scén, zhotovovaných při procházkách rodiny Lorda Arundella u Albury. Představil formu př́rodní promenády, přirozeně se vinoucí v krajině venkova. Cestu lemují solitéry a stará torza stromů, v přirozeném řádu zrození, proměn a zániku, který je odhalen a obdivován. Hollar, jak dnes dovozují někteří britští odborníci, patrně inspiroval princip postupného odkrývání krajinných scén, který byl zásadní pro krajinářské parky. Jak později zdůraznil William Gilpin (1724-1804), příroda oplývající bohatostí textur a barev (v průběhu doby se měnících, narušujíc tak neustále vnímanou scénu) je málokdy schopná sama vytvořit perfektní kompozici; zde musí pomoci umělec, třeba jen pečlivým umístěním stromu [Gilpin 1794].

Klasicistní estetika Gérarda de Lairesse (1641-1711) předefinovala na čas pojem malebnosti a renesancí i manýrismem rozvíjená malebnost prŕrody byla zavržena jako nebezpečí pro pravé, čisté umění i pro samotné umělce klasicismu, kteří se v takové divoké krajině se samou skálou, troskami a bažinami lehkomyslně potulují [Kotková 2010:

9 Mnohem později i císař Franz Josef uložil Juliu Mařákovi zachycovat lesní interiéry mocnářství. 
132]. Francouzský park se v hlavním prospektu nesmírného měřítka rozvinul k jedinému Bohu, do nekonečna nebeské klenby. Stromoví bylo teatrálně formalizováno v podobě francouzského bosketu, kde každý interiér podléhal geometrické symetrii a osovosti, v perspektivní prostorové iluzi přísných linií formálně upravovaných lemů stromořadí. Dobové ilustrace bosketů Le Nôtreových kompozic v Marly, Versailles, Chantilly aj. (z díla Antoine Josepha Dessaliera d'Argenville [1709]), dokumentují systémy hvězdic průseků, rozpracovanost interiérů bosketů, v ostrém kontrastu s prostředím lesních porostů (Hohe Waldung). ${ }^{10}$ Královské silnice (Routes Royales) byly od první poloviny 18. století vedeny krajinou co nejpříměji, v systému dopravních cest spojujících Paříz $s$ provinčními městy a přístavy, $v$ délce několika tisíc kilometrů. Se stabilním podkladem a štěrkovým povrchem měly zaručit rychlé spojení a být sjízdné za každého počasí, deště i sněhu. Jejich šíre byla dvacet metrů, s př́kopy a upravovanými alejemi až dvacet sedm metrů [Hersche 1990: 147-148]. Jednotvárné porosty bosketů, lesů v parkových úpravách, ale i okraje cest a silnic, byly ve snaze o jejich estetizování opatřovány formálními liniemi, bordurami a rytmickými řadami stromů, v kontrastu s přirozeným růstem, propůjčujíce jim programově formu a estetiku uměleckého, komponovaného díla.

Svobodnější prostředí Albionu otevřelo v 18. století prostor pro uplatnění nových forem krajinného umění, otevřeně se hlásícího k odkazu antiky a italské renesance a programově hledajícího inspirace v klasické a renesanční arkadské krajině pod Alpami a Apeninami. V Anglii boskety a výplně zahradních parterů byly nazývány Wilderness, jako prostředí i v rámci formálních kompozic divoká, rozmanitá zpěvným ptactvem, motýly, s biodiversitou př́rody vnášenou do zahrad. Lord Anthony Ashley Shaftesbury (1671-1713) znovu otvírá světu př́rodu, navazuje na renesanční myšlení, zdůrazňuje jednotu, vyšší řád přírody, potřebu kultivace ducha, citu pro přírodní krásno. Ve vodopádech a skalách opět nachází půvaby přírody, jejíž součástí je, jak zdůrazňuje, i člověk [Stibral, Dadejík, Zuska 2009: 28, 34]. Estetický vjem u člověka, jeho soud, je zrcadlením vyššího řádu, kde krása zůstává dílem Boha, př́rody; ta je i pro Jeana Jacquese Rousseaua (1712-1778) nevyčerpatelný zdroj jevů hodných pozornosti. Tuto pozornost ostatně dokumentuje již po polovině 17. století (1658) Komenského Orbis Pictus [1887].

Immanuel Kant (1724-1804) rozvíjí dále estetickou zkušenost, pocit záliby prostřednictvím lidské obrazotvornosti a rozumové úvahy. Účel krásy tkví v jejím ideálu, jímž je člověk; význam věcí tak spočívá v estetičnu, v konceptu (účelu, důvodu) uspořádání. Pocit vznešenosti sestává z jedinečné „vibrace“ či „rychlých změn“ pocitů, kontrastů, vjemů. Kantova estetika, stejně jako krása, harmonizuje představivost a porozumění do samo-obsažného a udržitelného pocitu potěšení, vytržení; je odkrytým substrátem, vlastní podstatou světa, přírody, přítomnou v každé tvưrčí činnosti. Př́roda, jako objekt vědeckých zákonů, je sama odpovědna za krásu svých forem. Johann Wolfgang von Goethe (1749-1832), který pokládal antiku za vrchol kultury, uctíval Saveryho pokračovatele Jacoba Ruisdaela (1628-1682), nazývaje jej básníkem mezi malírí. Krása stromu není spatřována $\mathrm{v}$ jeho zahradnicky upravované formě, krása kamene je odkrývána pohledu, vrací se př́rodní estetika v zobrazování stromů, skal, lesních porostů.

Při hledání identity, mimo odkazů antiky a renesance, malebnosti a krás př́rodních forem, romantismem a prrírodními vědami živený byl proud př́rodního krajinářství

10 Viz Le Blond [1986: 78-79, 94-95, 112-113]. 
v Americe. Absence tradiční evropské krajiny (se kterou by se člověk mohl ztotožnit) byla saturována obdivem $\mathrm{k}$ majestátní a vznešené přírodě, k jejím př́rodním fenoménům. Odkazy Saveryho, Ruisdaela, Claude Lorraina (1600-1682), Gasparda Dugheta (1613-1675), Johna Constabla (1776-1837) či Williama Turnera (1775-1851) byly rozvíjeny malíři do nově transponované arkadské krajiny amerického kontinentu Thomasem Colem (1801-1848), Albertem Bierstadtem (1830-1902), Fredericem Edwinem Churchem (1826-1900), Georgem Innesem (1825-1894) a dalšími. Inspirace však mnozí čerpali i v panenských krajinách tropických ostrovů. Volné uskupení hudsonské krajinářské školy našlo odezvu v širokých vrstvách a posílilo vztah k objevené estetice př́rody. Ten vyvrcholil koncem 19. a během 20. století zakládáním a legislativní ochranou národních i státních parků, jejich správou, jako území národního společenského významu. Starou anglickou krajinářskou školou (Lancelota Browna, Humphryho Reptona aj.), na kontinentě reprezentovanou knížetem Hermanem von Pücklerem, byla inspirována lesní estetika Heinricha von Salische [2008 in Stibral, Dadejík, Peprník 2010: 35-54], která se stala jedním ze základů krajinné architektury i lesnictví a ochrany krajiny v Severní Americe. V Anglii, Severním Irsku a Walesu byly mimo národních parků zřízeny Areas of Outstanding Natural Beauty (AONB), oblasti výjimečných přírodních krás, chránící území s význačnými krajinářskými hodnotami. Podobně v dalších zemích byla konstituována územní ochrana krajiny v řadě kategorií, od národních parků, přes chráněné krajinné oblasti, prrírodní parky, až po krajinné památkové zóny. Koncem 20. století tak zřetelně posílil zájem na ochraně tradičních hodnot v krajině; byly rozeznány jako ohrožené kulturní dědictví.

\section{Krajinný design jako estetický proces}

S tradiční krajinou spojuje estetiku krajiny Antrop, u něhož každá tradiční krajina (kulturní a historická) obsahuje jedinečný duch místa, jako definující identitu, symbolickou hodnotu, umožňující orientaci v prostoru a čase. Tradiční venkovské krajiny jsou dobře „čitelné“ a propůjčují daným místům a oblastem jejich charakter a identitu. To jsou důležité dědičné kořeny, kde symbolické a vjemové hodnoty jsou přijímány prostřednictvím esteticky vnímaných scenérií (krajinných scén). Také se zde dají nalézt důležité tradiční postupy a principy hospodaření a údržby krajiny, jejích struktur a měřítek (během 19. století již prostorově ustálených) tak důležitých pro rozmanitost druhovou i kulturní. Obsahují nepostradatelné znalosti udržitelných metod a postupů, nabízejí inspirace pro krajinu současnosti a budoucnosti, i pro její obnovu. Přestože krajiny minulosti nemohou být vzkř́íšeny, jejich cenné stopy mohou být zachovány a funkčně zapojeny do současné urbanizované skutečnosti [Antrop 2005]. Na tradičních principech a v tradičních měř́tkách strukturované prostředí krajiny může vrátit citovou jistotu a harmonický vztah člověka ke světu, ztracené během vrcholící technologické a průmyslové revoluce, dvou světových a dlouhé studené války. Tradiční uspořádání společnosti a jejího vztahu k přírodě a krajině doznalo zcela netušených a zásadních změn, jejichž důsledky se obrážejí i v současných postojích a zavedených schématech agro-industro-environmentálních vztahů ke krajině. Estetika krajiny se dostala na samotnou periferii zájmů a vnímání, jak ilustrují i následující odstavce. 
Estetika tvorby prostředí, designu krajiny, není jen estetikou výtvarnou, ale i estetikou životního dění, estetikou života, kde výtvarný dojem kontrastně podtrhuje dojmy mimovýtvarné, přírodní. Př́rodní složky, limitující lidskou potřebu, představy o uspořádání krajiny, fungují jako kontrast a narušení lidského řádu a mohou se stát nositeli estetična.

Jakýkoli předmět i jakékoli dění (at děj přírodní, at činnost lidská) mohou se stát nositeli estetické funkce. Týž jev, který byl privilegovaným nositelem estetické funkce $\mathrm{v}$ jisté době, zemi atp., může být této funkce neschopným $\mathrm{v}$ jiné době, zemi atd.; není v dějinách umění nouze o prrípady, kdy původní estetická platnost byla znovu odhalena teprve vědeckým zkoumáním. [Mukařovský 1971: 2-7]

Honzík v souvislosti s psychickými funkcemi v architektuře (urbanismu) hovoří o vlivech díla na lidské smysly, ducha, o působení dojmů výtvarných a mimo-výtvarných (prostorových, prostorově klimatických, provozních) o podvědomém vnímání atmosféry prostoru, která vyvolává libost či nelibost, pocit souzvuku či disharmonie. Prostorové i provozní dojmy podmiňují možnost výtvarných zážitků. Značnou váhu Honzík dává především uměleckému citu, který bude vždy směrodatným pro začlenění nové stavby do prostředí města, krajiny; žádné zásady ani pravidla nemohou být přijaty jako trvalá dogmata [Honzík 1944: 6, 33].

U Honzíka harmonizace prostř̌edí sama o sobě nevytvárí hodnotu, pouze dovršuje, korunuje dílo, jehož hodnoty byly vytvořeny řešeními programů provozních, klimatických a konstruktivních. Sebedokonalejší rovnováha, spořádanost a symetrie, dosažené chladným rozumem, postrádají estetického účinu, spočívajícího právě v porušení dokonalé kázně, normy. Chladná dokonalost je umrtvující a esteticky inertní. Konstatuje, že směry antiestetické zamítající harmonizaci (uvedení částí do vztahu k celku, která odpovídá konstitučnímu založení člověka) se uplatňují u architektur podnikatelských. Nezájem o stránku estetickou a psychologickou vyhovuje plně zájmům exploatačního prakticismu.

Podaří-li se nám dívat na svět jako na skladbu prostorů, na jednotlivou stavbu ne jako na samostatný svébytný celek, ale jako na součást jiného většího prostoru, který pomáhá vytvářet, nemůžeme dojít ani ke špatným závěrům urbanistickým, ani k omylům krajinným. [Honzík 1944: 22]

Příznivý poměr jednotlivostí mezi sebou a ve vztahu k celku je obecně dán harmonickými vztahy výšek a šířek (poměrů či formátů) navzájem a jejich vztahy $k$ výškám a širrkám prostranství. Již před válkou upozornil Mukařovský, že umění a zejména architektura ztratily cit pro materiál (brizolit, betonové střešní tašky, eternit atp.); nové hmoty nahradily tradiční materiály. Došlo mnohde i ke znásilnění lidských měřítek a k narušení tradičního obrazu krajiny (likvidace tradičního členění krajiny; krajina se stala výrobním prostorem). Postupně se tak vytratila i materiálová podstata charakterizující rozmanitost krajin. Podle Šindeláře se tak v druhé polovině 20. století zdá již jisté, že

... umění je zbytečné, přesahujíc hranice zájmů a pojetí světa. Hledisko ekonomizace se stává stále více rozhodující. Výsadba lesů, plodin, organizace krajiny se řídí 
přísně ekonomickými hledisky. V př́rodu se zavádí typ uspořádání, který jí není vlastní. [Šindelář 1969: 220]

V době třetí ŕíše princip krve a půdy „Blut und Boden“ byl součástí romantické národní zelené ideologie. Vědecký, rasistický sociální darwinismus Haecklův (monism) posloužil jako vědecký základ rasových myšlenek nacismu, pojem ekologie nabídl článek mezi nacionalismem, socialismem, rasou a ochranou prŕrody. Národní ideologie očištění (návratem k jednoduchosti německé lidové krajiny) od asfaltové kultury velkých měst a kapitalismu, měly sloužit návratu člověka k hospodářství, udržitelnosti a ochraně př́rody. Wiepking Jürgensmann společně s Konradem Meyerem navrhli množství environmentálních plánů, funkčních schémat a norem, kde člověk, příroda a vegetace byli ve společné harmonii, bez ohledu na místní tradice, komunity a př́běhy krajiny.

Krajinní plánovači měli na východě totální plánovací svobodu. Tradiční design krajiny, jako dlouhodobý tvořivý proces, byl na stolech architektů krajiny nahrazen okamžitými účelovými řešeními přesného funkčního uspořádání. Města byla přetvořena parky a zahradami, katalogové farmy s německými a holandskými kolonisty nahradily původní usedlosti. Ř́dké osídlení mohlo pomoci ekologickým plánům obnovit zdraví a stav venkovské krajiny a př́rody říše. Přírodní rezervace, zelené krajinné plány, organické farmy a vyhlazovací koncentrační tábory stály vedle sebe $\mathrm{v}$ surrealisticky podivném, fantasmagorickém a neuvěřitelném, leč skutečném klimaxu reálného, racionálně funkčního plánu. Racionálně funkční řešení pracuje pouze s okamžitou situací, odvádí zodpovědnost od jednotlivce a předává ji byrokracii. Místo jednotlivce, jako historického (za činy odpovědného) účastníka je zaměněno všezahrnující vizí historie, kultury, vše určujícího a řídícího politického systému [Muser 2010]. Ztrácí se tak (je institucionálně odepřena a bagatelizována) etická a morální odpovědnost jednotlivce za současné jednání a jeho důsledky. Němečtí krajinní architekti se $s$ entuziasmem podíleli na proměně východu k obrazu nové domoviny. Byli okouzleni možnostmi jejich odborné erudice a realizací plánů s absolutní volností. Ignorováním člověka, vizuálních struktur a hodnot krajiny s člověkem a jeho činností, zvyky a potřebami spjatých (v jejich pohledu cizích, nevýznamných) se mohli vlastní cestou podílet na realizaci konečného řešení [Brueggemeier, Cioc, Keller 2005: 145].

Nová architektura př́rodních prostor Ladislava Žáka měla vzniknout z potřeb společenské třídy pracujícího lidu, vycházejíc z prvků české krajiny. Po stránce lidsky obsahové se celá krajina měla stát bytem, domovem a rekreačním prostředím všech vrstev, zejména vrstvy lidové.

Nutnost a potřeba dobře ubytovat $\mathrm{v}$ př́rodě všechny lidi všech společenských vrstev je něčím nebývalým a novým a dává zcela nový a odlišný sociologický lidský obsah nové architektuře zeleně. Architektonická forma této nové architektury zahrad, sadů a krajin bude vytvořena - jestliže vznikne u nás - plným právem a zcela logicky z prvků naší české stř̌edoevropské krajiny, z její zdejší domácí př́rody a vegetace. Sloučením nového lidského lidového obsahu a nové architektonické formy, odvozené z prvků naší krajiny, může vzniknout nová svérázná architektura př́rodních prostor, jestliže opravdu organicky sloučí všeobecně platný lidový prvek s novou formou, odvozenou rovněž převážně z lidových civilních prvkủ české krajiny. [Žák 1942: 129-136] 
Někdejší Batův expert pro urbanismus, architekt Hruška, ve studii Příroda a osídlení, biologické základy krajinného plánování upozornil záhy na porušení harmonie krajiny, rozptylování zástavby do krajiny a navrhl sladit a harmonizovat vztahy mezi člověkem a př́rodou. Varoval před přicházejícím rozvratem venkova, sídel a tradičních struktur v krajině.

Je třeba, aby poznáním všech biologických závislostí v př́írodě se stala nutná omezení soukromého zájmu. Nelze v budoucnu připustit, aby se jako dosud parcelovalo a stavělo kdekoliv, cokoliv a jakkoliv. [Hruška 1945: 14]

Urbanismus nahlédl jako přežitek 19. století a vyzdvihl možnosti prostorového plánování. Konečným výsledkem měla být biologicky harmonizovaná krajina, esteticky dokonalá.

Vycházet $\mathrm{z}$ biologického souladu je jediná možná cesta při ozdravování krajiny; tedy: napřed dát krajině organický pořádek, řád, pak se estetické uspokojení, pokud jsou stavební a kultivační zásahy prováděny s porozuměním pro krajinu a její organické potřeby, dostaví samo. [Hruška 1945: 26]

Hruška věřil v ozdravění a harmonizování lidských a přírodních sil, v kultivaci kraje, v estetickou kapacitu, měřítko, hmotu a formu, obraz a siluetu; krajinu viděl jako nadřazený biologický celek. Nechtěl nic jiného než dobrý průměr produkce ve stavebnictví a ve formovém regionalismu spatřoval obranu proti postupujícímu rozkladu a ničení kulturních hodnot.

Dokud nenalezneme novou technicko sociální formu zemědělského sídliště, budeme muset vesnici bránit před rozkladem (v tom stáváme se jaksi památkári!) Musíme se snažit, aby sídelní celek byl prodchnut určitým tvarovým modulem, tedy základním laděním, jež pojí všechna lidská díla ve hmotě, výškovém rozvinutí, členění, materiálu atd. v celek... ale zásady a míry harmonie nelze normovat. [Hruška 1945: 27]

Jenže potlačení estetiky tradiční krajiny, měřítek, materiálů a po r. 1948 vznikající nová bytová i rekreační zástavba v krajině naplno potvrdily zavržení tradičních struktur a řádu v uspořádání krajiny, před čímž varovali Mukařovský i Honzík. To se obrazilo v jednostranném a pouze funkčně produkčním standardu prostorového plánování a organizace krajiny socialistického realismu a neofunkcionalismu. Smělá sídliště s absencí soukromých zahrad a sadů potřebovala další prostor v nezastavěné krajině, v bývalých vinicích, sadech, zahradách byla kobercově stavěna svérázná víkendová a prázdninová pseudosídla a osady, ve zdrobnělém (nikoli však lidovém) měřítku i detailu. V obrazu krajiny kontrastní transekt venkovských sídel byl nastolením prvoplánově funkčního řádu trvale proměněn. Tradiční estetika života byla nahrazena kolektivní indiferentností.

Ztráta schopnosti vidět svět celistvě a ve vzájemných organických souvislostech je zřejmá v neschopnosti vytvořit záměrný organický a stylový celek s vnitřní logikou 
a harmonií. Záměr není vyjádřen individuální formou, ale je naopak výsledkem standardní, mechanické a anonymní výroby, je obelstěním estetiky a hlavně člověka. Standard je dáván do prostředí, kde člověk chce standardu uniknout. [Šindelář 1969: 34-39]

Obytné soubory periferií měst se promítly v krajině sekundárními rekreačními periferiemi. Ozdravovací a funkčně harmonizační experimenty (pozemkové úpravy, kolektivizace, meliorace atp.) nevedly v krajině ke zrodu očekávaných estetických hodnot; ty zbylé mizí společně s ještě tradičními prvky dlouhodobě vžitého řádu hospodářského utváření. Přríroda i krajina se staly surovinovými zdroji a zastavitelnými plochami v plánech územního rozvoje a prostorového plánování. Pojem krajiny jako místa se všemi rozmanitostmi byl nahrazen indiferentním termínem prostor; ten je pak možný nově funkčně organizovat a plánovat, bez ohledu na jeho historii, proměny a tradice.

Na zásadní aspekt měřítka člověka a ideální formát obyvatelné, esteticky funkční a strukturované krajiny, koncem devadesátých let minulého století znovu upozornil až Nauman [1999]. Na základě ankety k estetice a charakteru krajiny mezi architekty a urbanisty, uvedl jako optimální pro současná venkovská sídla maximálně dvou etážový dům s podkrovím, tedy do výšky deseti metrů. Bydlení ve vyšším poschodí než třetím připouštělo cca $32 \%$, preferovalo však pouze $7 \%$, respondentů ankety. Určité procento připouštělo pro obchodní a administrativní funkce budovy větší výšky, avšak nepřevyšující výšku vzrostlých stromů. Vyšší stavby byly přípustné pouze jako tradiční architektonicko krajinné dominanty (věže kostelů, katedrály, rozhledny). To vše je zásadní pro architekturu, urbanismus a plánování krajiny, obory typicky mnohofunkční,

kde estetická funkce nabývá na dominantním významu účinem optickým, často teprve časem a naším způsobem zrakového vnímání a kde právě s oblibou zaujímá místo uprázdněné funkcemi ostatními. [Mukařovský 1971: 279] Architektonický výtvor ... je určen k tomu, aby sloužil jako prostorové prostředí činnostem druhu nejrůznějšího,...organizuje prostor obklopující člověka. Organizuje jej jako celek a vzhledem k člověku celému, tj. vzhledem ke všem jeho jednáním... [Mukařovský 1971: 274]

Estetická funkce vytváří vztah člověka ke skutečnosti, brání převážení jediné (totalizující) funkce nad všemi ostatními. Zároveň však nemá žádný konkrétní cíl, nesměřuje k plnění žádného praktického úkolu; spíše vyřad’uje věc nebo činnost z praktických souvislostí.

Právě tím, že (estetická funkce) postrádá jednoznačného obsahu, stává se průhlednou, nestaví se k ostaním funkcím nepřátelsky, ale pomáhá jim. Jestliže ostatní praktické funkce, ocitnou-li se vedle sebe ve vzájemné konkurenci, usilují převládnout jedna nad druhou, uplatňujíce směřování k funkční specializaci (k monofunkčnosti, jejímž vyvrcholením je stroj), směřuje umění právě vlivem estetické funkce k mnohofunkčnosti co nejbohatší a nejmnohostrannější... [Mukařovský 1971: 43-44] ... estetická funkce pomáhá člověku přemáhat jednostrannost specializace, ochuzující nejen jeho vztah ke skutečnosti, ale i možnost jeho jednání 
vůči ní. Nezabraňuje tvůrčí iniciativě člověka, ale pomáhá ji rozvíjet. [Mukařovský 1971: 154-155]

Zůstává-li nerozpoznána, bagatelizována, promarněna, či záměrně je odvržena vlastnost estetické funkce korunovat, harmonizovat (udržovat v rovnováze) či nahrazovat funkce jiné (provozní, hospodářské atp.), ztrácí se pojistka před zásadními změnami v harmonii a jednotě prostř̌edí, v environmentální, společenské a sociální oblasti. Odcizení od této jednoty má za následek estetický a tím i etický úpadek našeho vnímání a cítění [Lorenz 2000]. Rozpad etického vnímání, odpovědnosti morální a mravní, se obráží i na způsobu kolektivně anonymního jednání vůči ostatním živým tvorům, krajině, přírodě. Vztah společnosti ke krajině, k životnímu prostředí, je vypočten a vymezen surovinově energetickými toky a normovanými agro-industriálně-enviromentálními vztahy k složkám př́rody, zdrojům. Starost o tradiční krajinu je svěřena rozvojovým prvoplánům. „Falešné dílo, cenné pro netrpělivé duchem, jež rádi ušetří hodně času, který by byl tř̌eba na důkladné studium díla př́rody a lidských skutků.“ [Da Vinci 2010: 127-128] Nikoli skutečný obsah, ale pouhá plocha a její výkaz jsou objekty zájmu. „Ó lidská hlouposti, nechápeš, že se dopouštíš stejného omylu jako člověk, který osekává větve stromu, ozdobené listy a voňavými květy nebo ovocem." [Da Vinci 2010: 128] Rozhodující je dnes pouze produkční funkce a tržní hodnota, které je podrobena př́roda, ekosystémy, biodiversita, člověk a jeho dílo. Kdysi přirozené limity přírody, s ohledem na současné technologie, již nemají regulační funkci. Člověk překročil své měřítko a z něj vzešlé poměry v krajině, je jako jednotlivec zbaven esteticko etických a morálních povinností a zábran, převzatých kolektivní byrokracií (kraje, rezortu, státu, společenství) a dopad je zásadní. ${ }^{11}$ Svoboda volby je nakonec stejně rízena nevolenou mocí a totalitou trhu, peněz. Současné teorie nového urbanismu, transektu, udržitelného hospodářství př́městského venkova (new residential sustainable farming communities $\mathrm{v}$ USA) se vrací $\mathrm{k}$ poměrům rodinných farem, tradičně strukturovaných malých sídel, $\mathrm{k}$ měřítku členění katastru a snaží se nalézt odpověd’ na současnou krizi krajiny, byt' jejich praktický dopad spočívá v minoritě specializovaných komunit [Lerner 2011].

Estetické hodnoty krajiny neumíme v současné praxi (jako společnost) zřetelně rozpoznat, uchopit a účinně chránit, nejsou předmětem územně rozvojových schémat a plánů (byt lze předpokládat určitý potenciál v realizaci pozemkových úprav či územních systémů ekologické stability, jichž se mohou stát součástí, jsou-li s takovými aspiracemi vytvářeny). Tradiční prvky a formy krajiny jsou nahrazovány lacinými a provozně zjednodušenými normovanými řešeními (např́klad tradiční ovocná stromořadí a aleje mizí, jsou nahrazovány, pokud vůbec, lacinými, pro krajinu funkčně i významově prázdnými, mnohdy i náletovými druhy dřevin). Edible landscape, americkými kolegy nedávno znovuobjevený a uctívaný fenomén, je tak mnohde proměňován na sterilní, významově vyhaslou krajinu. To je nedobré pro specifickou regionální i obecnou kulturu prostředí, která vrcholí monofunkčností, před kterou při veškerém omezení své doby varoval již Šindelář:

11 Jako reakce vznikl dokument Evropská úmluva o krajině. Úmluva se věnuje krajině pozoruhodné, běžné i narušené. Předmětem úmluvy je krajina př́rodní, venkovská, městská i industriální. Ochrana, správa a plánování krajin jsou podle úmluvy právem a povinností každého jednotlivce a všech evropských zemí. Viz http://geography.ujep.cz/geo_s/st_opory_s/prilohy/kraj_plan_umluva_o_krajine.pdf. 
Je-li systém bytostných potřeb potlačen a zaměněn za systém funkcí, dochází k vážným poruchám ve společenském životě. Funkce má tendenci standardizovat naše potřeby, produkty a psychický život. Stabilizuje se postupně v autoritativní normu, která diktuje našemu počínání. Má tendenci zjednodušovat a okleštovat náš vztah k životnímu prostředí. Také náchylnost měřit vše kvantitativně projevuje se jako snaha redukovat skutečnost na měřitelná a ověritelná fakta a data, na jednoznačný výkaz funkce. Jedinec se stává funkcí, obecninou a je mu upřen význam, člověk je redukován na jednu dimenzi a podobá se tak stroji nebo materiálu, jeho hodnota je měřena jeho výkonností. Jedinec se stává divákem a ne účastníkem světa. Je to degradace člověka na skupinu životních a sociálních funkcí. [Šindelár 1969: 235-236]

Estetická hodnota krajiny, dynamického rozhraní řádu člověka a př́rody, spočívá v harmonické jednotě celku s pestrou obsahovou diversitou umělých a přírodních prvků a jejich kontrastů. Je spjata s př́rodní (lidskou potřebou usměrňovanou) sukcesí v krajině, $s$ měřítkem člověka, $s$ kapacitou jeho pohledu a vnímání, kde vnímanými objekty jsou i fragmenty $\mathrm{v}$ krajině prolnuté přírody. $\mathrm{V}$ zákonitostech lidského díla se obráží řád př́rody, v prŕrodě se zrcadlí lidský genius; tak dlouho, dokud tradiční hospodářské narušování této křehké harmonie zůstává v mezích lidského měřítka, poměrů hmot a prostorů, $\mathrm{v}$ čistotě tradičních forem i materiálů. „U duchů kultivovaných se umění obráží v př́rodě a propůjčuje jí svůj lesk. Nadvláda estetické funkce je tu vnesena zvnějška." [Mukařovský 1971: 6]

Rozdílné klimatické, půdní a geologické podmínky, morfologie a staletí tradičního hospodaření vytvořilo v celé Evropě bohatou a druhově rozmanitou mozaiku kulturních a př́rodních krajin. Jedině udržitelnou správou těchto mnohofunkčních, kulturně historických krajin a jejich biodiversity můžeme uchovat cenné ekosystémové služby při současném zachování jejího kulturního a př́rodního dědictví [EEA 2010]. Estetická hodnota krajiny je dnes společensky konstituována normou, pravidlem. ${ }^{12}$ Přestože je předmětem zákonné ochrany, estetická hodnota jako podstata tradiční krajiny není často rozpoznávána a rozlišována mimo prostory chráněných krajinných oblastí, př́rodních parkủ či krajinných památkových zón. Historické mapy vojenských mapování i mapy stabilního katastru tvoří ideální, detailní podklad krajinářské, konzervátorské i tvưrčí praxe v rámci těchto území. Jejich vypovídací hodnota by však mohla pomoci i k lepšímu porozumění, čtení př́iběhů utváření krajin i mimo ně, v nechráněné krajině, kde absence významnějších přírodních prvků ještě vůbec nemusí znamenat, že se jedná o krajinu nehodnotnou. Naopak, řada autorů, věnujících se problematice estetiky krajiny vychází z kulturně

12 Estetická hodnota tradičního rázu (charakteru) krajiny je z hlediska současné legislativy stabilizována pravidlem, celoplošně chránícím mj. kulturní a historickou charakteristiku místa, kulturní dědictví minulosti. Zákon (č. 114/1992 Sb., o ochraně prrírody a krajiny ve znění pozdějších změn) v $\$ 12$ o ochraně krajinného rázu vychází z celoevropsky přijaté normy, zájmu na celoplošné (ochrana krajinného rázu je ochranou obecnou, platí tedy na celém území státu) ochraně krajinného rázu (vyjádřeného především morfologií terénu, charakterem vodních toků a ploch, vegetačního krytu a osídlení), jako součásti kulturního dědictví minulosti a příznivého životního prostř̌edí budoucích generací, kde přírodní, kulturní a historická charakteristika místa či oblasti je chráněna před činností snižující jeho estetickou a prírodní hodnotu. 
historických, estetizujících projevů člověka v krajině [Newton 1973], fenomenologicky ${ }^{13}$ z poznání a vnímání krajiny, jejíž význam a estetická hodnota je vázána na dílo (přítomnost) člověka a hledá i nové (environmentální, kognitivní) interpretace [Norberg-Schulz 1994]. Člověk je okem přírody, estetika sídlí v jeho pohledu. Vnímání i utváření krajiny je jedinečnou součástí tohoto pohledu.

Krajinu tvoří (at' už přímým zásahem nebo pouhým zaměřením pozornosti) vždy člověk. Příroda, považovaná $\mathrm{v}$ případě předchozích paradigmat v různém smyslu za neredukovatelný, bytostně přítomný vnějšek lidského světa, je vtahována dovnitř a jejím interpretačním rámcem se stává svět primárně lidských záměrů a cílů... Estetickou hodnotu krajiny bychom proto mohli situovat na hranici průniku dvou rámců, se snahou zachovat a chránit roztříštěný přírodní rámec před tlakem kulturně-sociálního rámce. [Zuska, Dadejík 2006: 28, 44]

Krajina je dynamickým rozhraním řádu přírody a řádu lidského, kde vzájemné interakce, narušování ( $v$ mezích daných měřítkem, tradičními poměry, postupy), mohou být nositeli estetických hodnot. Strukturované napodobování a estetizování přírody, tvorba vizuální formy, se staly podstatou umění nejen zahradnictví, parkové tvorby, ale i designu krajiny; př́rodní prvky jeho součástmi (třeba jako kontrastní pozadí, nenarušený jednotící rámec prostorové scény).

Hodnoty př́ríodní (člověkem poznané) nakonec růstem, zráním, stárnutím a rozpadem (refugia, doupné stromy) mnohdy převáží nad estetickými hodnotami kulturně historickými, kompozičními, zanikajícími změnou či ztrátou původního poslání, absencí péče a údržby. Př́rodními procesy (rozpoznanými a předpokládatelnými) narušený umělý řád (alejí, stromořadí, krajinné kompozice aj.) by měl být rozeznán jako esteticky funkční a hodnotný stav krajiny (kontrastem jednotlivých prvků a jejich proměn, pestrostí detailu, zabarvení, akcentů aj.), kde jsou takto umocněny původní estetické funkce a hodnoty prostorotvorné, kompoziční.

Často se jedná i o esteticky hodnotnou formu přírodovědné význačnosti, přírodního detailu, archetypu, materiálu, př́rodního vzoru (například u památných stromů, nikoli jen patina, která také zvyšuje účin estetický) [Durdík 1875: 411-412]. Starý specimen prastarého stromu, coby pozůstatek kompozice krajiny, parku, solitér ve vinici, na louce, v poli, na mezi či u cesty, ale i pralesní interiér, či údolí ŕíční krajiny, geologický odkryv, jsou nejen prŕrodními hodnotami (refugium, doupný strom, výskyt vzácného druhu, hmyzu atp.), ale mnohdy i podstatou, archetypy, z př́rody často přejímanými a napodobovanými, estetizovanými. Jsou esteticky hodnotnými př́rodními archetypy (přírodní vzor, solitér, sošný objekt, tradiční materiál, druh), rozpoznaným návratem původní přírodní formy, odhalením zdroje, podstaty, člověkem vnímané, přejímané a napodobované krásy.

Aspekt odhalování a zakomponování přírody, jejího řádu, byl součástí zahrad a parků manýrismu i podstatou malebných krajinářských a dramatických romantických parků

${ }_{13}$ Fenomenologie (z řeckého fainomai, ukazuji se), znamená obecně přesné zkoumání jevů. Místo zkoumání podstat a skutečností samých se zabývá zkušeností, tím, jak se věci, i příroda, samy člověku ukazují; člověk je okem prrírody, kterým se príroda sama na sebe dívá. 
v krajině. Nejprve umělým komponováním malebné krajiny venkovských sídel, v ohromujícím měřítku jednotné a vznešené kompozice přírodních segmentů a prvků, podrobených př́rodnímu řádu a jeho procesům. Později romantickým dotvářením divokých a drsných prrírodních míst skalních výchozů, roklí a říčních údolí jejich zpřístupněním, zprůchodněním a akcentováním výhledů na dramatické detaily a panoramata okolní přírody a krajiny. Sem také sahají počátky kolektivního rozpoznání estetických hodnot znovu objevené a poodkryté př́rody, rozmachu nejen turistiky, ale i ochrany přírody a krajiny, zrozené z poznání etické a morální odpovědnosti tyto hodnoty zachovat a udržovat.

V krajině sídel minimalizovaná příroda privátních zahradních oáz s racionalizovanými porosty, zdobnými fontánami a sbírkami minerálů, je v tradičním veřejném prostoru rozvíjena fontánami, kašnami, dlažbami, sloupy a sochami, jež doprovázejí otevřená prostranství spolu s ovocnými stromy sadů, vodními prvky, solitérními stromy návsí (místní či symbolické provenience), stromořadími a alejemi ulic a náměstí. Strukturovaná př́roda je výraznou estetickou hodnotou městské krajiny, kontrastně narušující funkční dokonalost města jako stroje, harmonizující ostatní racionálně vykalkulované a umělé provozní funkce.

V prrírodní a př́rírodě blízké krajině spatřujeme estetické hodnoty v původnosti a přirozené, mnohdy v dobré víře člověkem poodhalené archetypálnosti přírodních prvků. V krajině urbanizované a hospodářské byly tyto prvky uměle instalovány, proměňovány, organizovány a uspořádávány $\mathrm{v}$ rámci složitého systému vztahů a s ohledem na potřeby člověka. Staly se nedílnou součástí obývané krajiny, estetiky života. Stromy a porosty v podobě dominantních solitér, stromořadí a alejí (růstem a strukturou z př́rody pečlivě vybraných vzorových, symbolických či užitných druhů), hory a horniny v podobě skal a balvanů, skalek, drobných lomů, kamenných zídek cest, mezí a teras, rozcestníků, stél a soch, často v kontrastní kompozici se stromy; podobně jako vodní prvky doprovázené přirozenými porosty i uspořádanými liniemi.

Lapidárně čistými, místně tradičními formami, druhy, autentickými materiály a strukturovanými postupy tak docházelo k naplnění předpokladů a možností prostoru, místa, morfologie terénu, krajiny; zde estetická hodnota celku se obráží v ostrosti a kontrastech př́tomných jednotlivých složek, prvků a jejich estetických funkcí. Naopak sukcesí (expanzí, nikoli však invazí) znovu osídlené polohy mezí, okrajů starých cest, úvozů, břehů, mohou být esteticky funkčním narušením hospodářsky nefunkčního a opuštěného lidského uspořádání, vizuálním zvýrazněním a odhalením jeho reliktů i potvrzením prrítomnosti přírodního řádu na zbytcích tradičního uspořádání prostoru (př́rodní kolonizace). Takovéto dynamické prolnutí řádu člověka a přírody (v ideálním případě trvale udržované a spravované), je nejen esteticky funkční a hodnotné, ale významné z hlediska zvýšení retenční schopnosti krajiny, udržení a zlepšení biodiversity. Ta je dnes často zcela závislá na trvalém zachování těchto kontrastních (esteticky funkčních) a přechodových poloh přírodního a umělého řádu.

\section{Závěr}

Estetické hodnoty krajiny jsou neopakovatelné a jedinečné, jsou obrazem vývoje a proměn osídlení, charakteru i duchovního a etického života společnosti, estetikou ži- 
vota; krajinu přece neděláme pro cykloturismus. Estetické hodnoty prrírodních charakteristik krajiny (vycházejíce z konstrukce přírodní estetiky, environmentalismu a potvrzené staletími zájmu umění, filosofie i přírodních věd), se tak obrážejí i v přírodních hodnotách, které se také jeví být jejich mírou, obrazem a potvrzením.

Utváření, design a plánování krajiny a sídel se neobejde bez schopnosti předjímání či predikce výsledku, celkové struktury, obrazu (díla, stavby, činnosti), které budou po stránkách funkčních (i esteticky) dokonalé. Právě proto hledáme inspiraci v minulosti (minulé přítomnosti, jež je nedílnou součástí našeho světa a poznání), kdy kontrastní prvky lidského díla i př́rody měly nezastupitelná místa v dynamicky vyváženém uspořádání krajiny. Je tak odkrývána podstata věcí, daná i měřítkem, ostrostí a kontrasty ${ }^{14}$ významných prvků a segmentů, charakteristických materiálů (geologický substrát a jeho povrchové prvky, vodní prvky, porosty, okraje, solitéry, př́rodní i uměle vytvářené dominanty, prostory, oblasti, cesty, ohniska atp.), ale i jejich predikcí, narušováním, zviditelňováním, strukturováním a kompozicí, s ohledem na přírodní procesy a potřeby člověka, naplňujíc jeho vlastní bytí v prostoru krajiny.

Je-li toto kontrastní prolnutí, dialog člověka s přírodou esteticky funkční v jednotlivostech, bude s velkou pravděpodobností esteticky hodnotné i jako celek. Míra této hodnoty (celkové libosti) je (podobně jako u hudby) dána netoliko harmonií, jednotou celku, ale především ostrostí, kontrasty a akcenty dílčích složek, segmentů a prvků, umělých a přírodních. Spočívá také v čistotě forem a detailů, v patřičnosti a autenticitě materiálu, porostní skladby, ozřejmujících, potvrzujících a zvýrazňující samotnou (vnímanou a rozpoznanou) podstatu svých (přírodních a kulturně historických) prostředí. Nejen poznání (na základě studia, predikce terénu, přírodních procesů, minulých i stávajících struktur), ale dlouhodobá, trvalá poučená péče a management jsou nepostradatelné.

Umění designu krajiny, vizuální plánování, koncept místa a vztahů jednotlivých prvků a jejich výsledná vizuální forma by neměly být jen pouhou okamžitou (zpravidla ohromující a překvapivou) stavbou, instalací (jako pouhý nápad, objekt, architektura), ale výsledkem složitého, dlouhodobého, stále se proměňujícího, interaktivního procesu, který obsahuje hlubší poznání podstaty věcí a jejich vazeb, včetně komplexního uspořádání prostorových a provozně funkčních vazeb a souvislostí. Umění nehledá duši ve věcech, ale samotného ducha věcí. Je to umění predikovat poznané přírodní procesy a vycházet jim vstříc (například řízená sukcese, hledání podstaty, krásy vzorů a archetypů prrírody a jejich přirozené zviditelnění s ohledem na charakter místa, nikoli však kýčovitá náhrada, překvapivé dotváření novotvary), ${ }^{15}$ včetně omezení se na postupy a technologie, jež jsou s tímto poznáním v souladu, dříve tradiční lidová či selská moudrost. Věci, objekty, prostory mají být právě jen tím, čím skutečně jsou. Ostatně konečným

${ }^{14}$ Např. esteticky působivý kontrast drobného měř́tka podhorské vesnice v poměru s mohutností okolních hor, kontrast etruských měst a vesnic na vrcholcích a výchozech v toskánské krajině; na druhou stranu odpudivá absence kontrastu, okraje současných sídel, rozlévajících se v jednotvárně uniformní zemědělské krajině, zbavené zbytků tradičních hospodářských struktur.

15 Strukturování a uspořádávání stávajícího řádu, kde významná je dominantní funkce vybraných klimaxových dřevin, solitérů i linií ve struktuře tradičních hodnot krajiny, nebo obdobně význam místních, zdomácnělých krajových odrůd ovocných dřevin atp. Na druhou stranu je pochybené a nevhodné přetváření tohoto řádu, často zavlékáním „krásných“ či jinak „perspektivních“ zahradnických výpěstků „à la mode“ do krajiny; jejich místo je v uzavřené zahradě, v arboretu s vlastní estetikou funkce a hodnoty sbírkové. 
cílem není racionální kalkul, pouhý fyzický tvar, ale především kvalita a čistota jeho obrazu v lidské mysli [Lynch 1960: 118-119].

\section{Poděkování}

Př́íspěvek vznikl jako úvod do problematiky $\mathrm{k}$ řešenému projektu MKČR DF12P01OVV050.

\section{LITERATURA}

Antrop, Mark. 2005. „Why landscapes of the past are important for the future.“ Landscape and Urban Planning 70: 21-34.

Benzoni, Gino. 2004. Verso la Santa Agricoltura - Alvise Cornaro, Ruzante e il Polesine. Collana: Rapporti/ Polesine e Cultura padana.

Brueggemeier, Marc, Franz-Josef Cioc, Thomas Zeller. 2005. How Green Were the Nazis?: Nature, Environment, and Nation in the Third Reich. Athens: Ohio University Press.

Comenius, John Amos. 1887. Orbis Sensualium Pictus. Syracuse, New York: C. W. Bardeen.

Da Vinci, Leonardo. 2010. Deníky. Praha: Československý spisovatel.

Dessalier d'Argenville, Antoine Joseph. 1709. La Theorie et la Pratique du Jardinage. Paris.

Durdík, Josef. 1875. V̌̌eobecná aesthetika. Praha: I. L. Kober.

EEA (Evropská Environmentální Agentura). 2010. 10 messages for 2010 Cultural Landscapes and Biodiversity Heritage. [online] [cit. 18. 6. 2011] Dostupný z: http://www.eea.europa.eu/publications/10 -messages-for-2010-2013.

Gilpin, William. 1794. Remarks on Forest Scenery and other Woodland Views (relative chiefly to Picturesque Beauty) ilustrated by the Scanes of New Forest in Hampshire. Vol. II., 2nd edition, London: Gillpin.

Gojda, Martin. 2000. Archeologie krajiny. Praha: Academia Praha.

Hersche, Peter. 1990. „Die französischen Physiokraten - Vorlaufer der Grünen oder Bahnbrecher des Agrobussines?" Zeitschrift für Agrargeschichte und Agrosoziologie 38: 145.

Honzík, Karel. 1944. Úvod do studia psychických funkcí v architektuře. Knihovna architektury, rada II. Svazek 1. Nákladem a tiskem Dr. Ed. Grégra a syna v Praze.

Hruška, Emanuel. 1945. Př́roda a osídlení, biologické základy krajinného plánování. Knihovna Architektury, řada II., Svazek 2., 1/1945.

Jellicoe, Geofrey, Susan Jellicoe. 1975. Landscape of Man, shaping the Environment from Prehistory to the Present Day. London: Thames and Hudson.

Kotková, Olga (ed.). 2010. Roelandt Savery: malír ve službách císaře Rudolfa II. Praha: Národní galerie v Praze.

Le Blond, Alexander. 1986. Die Gärtnerei. Leipzig: Leipzig Buchbinderische Weiterverarbeitung: Kunst und Verlagsbuchbinderei Leipzig.

Lerner, Jonathan. 2011. „Your sub-division.“ Landscape Architecture Magazine 101 (2): 6-7.

Lorenz, Konrád. 2000. Osm smrtelných hříchủ. Praha: Academia.

Lynch, Kevin. 1960. Obraz města. Praha: Bova Polygon.

Mukařovský, Jan. 1971. Studie z estetiky. Praha: Odeon.

Muser, Mark. 2010. Nazi Oaks. Advantage Inspirational.

Nauman, Pavel. 1999. „Př́íspěvek na kolokviu: Péče o krajinný ráz.“ Pp. $92-99$ in Ivan Vorel, Petr Sklenička (eds.) Sborník prédnášek a diskusních príspěvkư z kolokvia Péče o krajinný ráz, cíle a metody, konaného 17.-18. 2. 1999. Praha: ČVUT.

Newton, T. Norman. 1973. Design on the Land: The Development of Landscape Architecture. Cambridge: Harvard University. 
Norberg-Schulz, Christian. 1994. Genius loci. Praha: Odeon.

Panofsky, Erwin. 1981. Význam ve výtvarném umění. Praha: Odeon.

Piccolomini, Aeneas, Sylvius. 1959. Memoirs of a Renaissance Pope, The Commentaries of Pius II. New York: Putnam.

Salisch, Heinrich. 2008. Forest Aesthetics. Durham: Forest History Society.

Sannazaro, Jacopo. 1966. Arcadia and Piscatorial Eclogues. Detriot: Wayne State UP.

Schama, Simon. 1996. Landscape and Memory. New York: Random House.

Schopenhauer, Arthur. 1969. The World as Will and Representation, Vol. I, 3. Book. Dover.

Stibral, Karel, Ondřej Dadejík, Vlastimil Zuska. 2009. Česká estetika př́rody ve středoevropském kontextu. Praha: Dokořán.

Stibral, Karel. 2010. „Lesní estetika Williama Gilpina a Heinricha von Salische.“ Pp. 35-54 in Karel Stibral, Ondřej Dadejík, Michal Peprník (eds.). Kauza les: Environment jako estetický problém. Olomouc: Univerzita Palackého.

Šindelář, Dušan. 1969. Tržiště estetiky. Praha: Obelisk.

Zuska, Vlastimil, Ondřej Dadejík. 2006. „Krajina jako maska přírody: estetika subverze versus estetika konformity." Estetika 44: 28-43.

Žák, Ladislav. 1942. Architektura IV.

\section{SUMMARY}

The balance of ecological and productive functions of the landscape, keeping at the same time high aesthetic and cultural values was the product of a mastered human intervention (applied in a concrete context) within its physical limitations. The development of articulated landscape mosaics indicates that the aesthetic appeal is the result of a human desire for spatial order, purity and boldness of forms. The skills able to harmonize with the nature to this ideal developed during the long centuries of practice. While some features were sought by design as local inhabitants applied their instinct for rational spatial organization, many landforms developed spontaneously as nature, in its turn, adapted to human activities. Over centuries, a stabilised systems of footpaths (often in their prehistoric trajectories, given by the natural and landform limitations), hedgerows, tree stands and natural wetlands remained stable and unchanged, supporting a variety of wildlife and sustaining landscape stability. This scenery was reflected in more carefully designed landscapes of surrounding nearby noble estates, comprising ornamented farms, gardens and parklands, divided by often majestic tree avenues that underlined the hierarchy of the communication systems.

The continuous investment made in shaping the landscape by enhancing its appeal and productivity is comparable to a work of art, in which the aesthetic character of the result was not by accident but was considered a coronation of all the effort deployed to optimise landscape productivity. In our days, when productive function of the landscape has lost its meaning, the aesthetic function has taken its place, symptomatically along with the ecological function. The goal of restoring the internal harmony of the inherited landscape is to reinforce this unique functional symbiosis between aesthetics and ecological functionality which is increasingly at risk. The maps of Stabile Cadastre graphically illustrated the mastered compromise that was achieved in the early 19th century by applying long lasting human efforts in managing the spatial organisation of nature. 